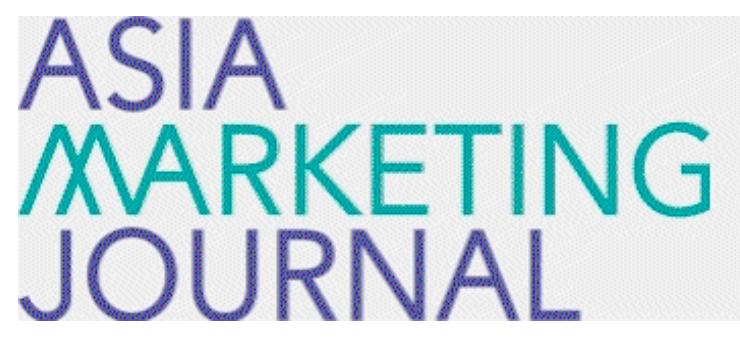

ASIA MARKETING JOURNAL

Volume 15 | Issue 1

Article 9

4-30-2013

\title{
TONYMOLY Cosmetic Company
}

Ji Hee Song

jiheesong@uos.ac.kr

Sung Ho Lee

Follow this and additional works at: https://amj.kma.re.kr/journal

Part of the Marketing Commons

\section{Recommended Citation}

Song, Ji Hee and Lee, Sung Ho (2013) "TONYMOLY Cosmetic Company," Asia Marketing Journal: Vol. 15 :

Iss. 1 , Article 9.

Available at: https://doi.org/10.53728/2765-6500.1515

This Article is brought to you for free and open access by Asia Marketing Journal. It has been accepted for inclusion in Asia Marketing Journal by an authorized editor of Asia Marketing Journal. 


\section{TONYMOLY Cosmetic Company: A Small but Smart Marketing Player}

Established in 2006 as the forward integration effort by Taesung Industry, the major cosmetic packaging company. TONYMOLY has phenomenally grown to one of the major cosmetic brand companies in the submarket called, 'one brand-shop' of cosmetic market since 2008, after overcoming the crisis of 'going out of business' in a couple of early years. Within a relatively short period of time, TONYMOLY's performances have dramatically improved in terms of metrics such as growth in sales revenue, the number of stores, the average sales per store, transaction value per customer, the number of monthly transactions, the number of membership-based customers, and overseas sales.

In this case study, we have examined TONYMOLY's recent marketing activities which may explain the plausible reasons behind the substantial growth of a small but smart cosmetic company. Above all, the first key success factor of TONYMOLY would be found in its adherence to the clear philosophy of the customer value proposition and/or the differentiated position of TONYMOLY as a brand of providing value. Second, this brand concept of value was first penetrated and welcomed among the foothold customer target group of mid and late teens with appropriate products, while the target groups were later expanded into the age group of twenties along with expansion of relevant products. Third, its differentiation efforts have been concrete and meaningful by utilizing unique ingredients in its product development and marketing efforts, unique fun packaging, and continuously introducing new hit-selling products as well as managing steady-selling products. Fourth, TONYMOLY has been smart enough to use its limited marketing money efficiently and effectively in its marketing communication activities. Viral marketing. PPL, and concentrated media planning and execution turned out to produce effective and efficient market-based performances such as awareness, wordof-mouth, and sales. Lastly, the marketing leadership of CEO and top management, emphasizing communications and interactions, was confirmed in the relationship quality with and trust level of its franchisees and internal employees. These key success factors may explain the recent phenomenal market performances of TONYMOLY.

\footnotetext{
* First Author. Associate Professor. University of Seoul, Korea (jiheesong @uos.ac.kr)

** Corresponding Author, Professor, University of Seoul, Korea(shlee@uos.ac.kr)
} 
Despite recent successes, the major issues are presented for TONYMOLY to consider for maintaining its sustainable advantages and growth. The first issue concerns TONYMOLY's choice of growth philosophy between product/brand-centric marketing and customer-centric marketing. The second challenging issue relates to how TONYMOLY can cope with 'growing pains' plausibly accompanied with the rapid growth.

Key words: Differentiation Efforts, Customer Value Proposition, New Product Development, Born-Global, Efficient Media Planning \& Execution, Marketing Leadership, Brand-Shop, Korean Cosmetic Industry

On the way back to Seoul in the train of KTX after business trips of meeting the store owners, Mr. Joong Cheon Kim, CEO of TONYMOLY, was immersed in memories of how he and the company employees had gone through tons of crises and hardships to achieve the phenomenal growth of recent four years. Despite successful performances, he pondered how he could lead sustainable growth as well as cope with so-called 'growing pains' accompanied with the rapid growth. He decided in his mind that he and his team needed to improve the marketing plan for the next year as well as mid-to-long time horizon in a more thorough and systematic way, but was not concerned much as long as his company adhered to the marketing principles that the answer should always come from customers and marketing activities must be implemented with 'One-Mind' of employees.

\section{Company Background \& Major Performances}

\subsection{History \& Recent Evolution}

TONYMOLY was established in 2006 as the forward integration effort by Taesung Industry, the major cosmetic packaging company. Overcoming the crisis of 'going out of business' in a couple of early years, it has phenomenally grown to one of the major cosmetic brand companies in the submarket called, 'one brand-shop' of cosmetic market since 2008.

TONYMOLY develops and distributes $\cos ^{-}$ metic products including make-up, skin care, hair care, and body care. TONYMOLY means 'putting style into packaging,' combination of the English word TONY meaning 'stylish' and the Japanese word MOLY meaning 'to package.' Under the vision of 'Global Cosmetic Brand," TONYMOLY strives to fulfill the needs of 
modern customers with excellent quality products and stylish product cases. Based on extensive research and technological developments, TONYMOLY has developed various functional cosmetic products that are specialized in brightening and reducing wrinkles.

Despite the overall economic slow-down of consumption in Korea, TONYMOLY has achieved a phenomenal growth for the last 3 years. Sales revenue has shown the rapid growth from 18 billion Korean won in 2008 to 170 billion won in 2011 (See〈Exhibit 1)). Higher sales volume of about 250 billion won is expected in 2012. TONYMOLY has been expanding stores in the major areas. By 2008, TONYMOLY had opened just over 60 shops in Korea. Within 3 years, the number has grown to more than 300 . Moreover, with the aggressive pursuit of growth through globalization, TONYMOLY now operates about 200 shops in 14 countries (see 〈Exhibit 2〉). In this respect, TONYMOLY can be called a kind of "bornglobal' companies (Rennie 1993).

Moreover, the rapid growth of TONYMOLY's performance is proved by different measures such as transaction value per customer and the number of transactions (see 〈Exhibit 3〉). Average ticket value per customers has grown to be 18,000 won in 2011, which is doubled compared to 9,000 won in 2008. Average number of monthly transactions has increased up to 650,000 per month, which is more than tripled compared to 2008 .

〈Exhibit 1〉 Total Sales and Number of Stores of TONYMOLY

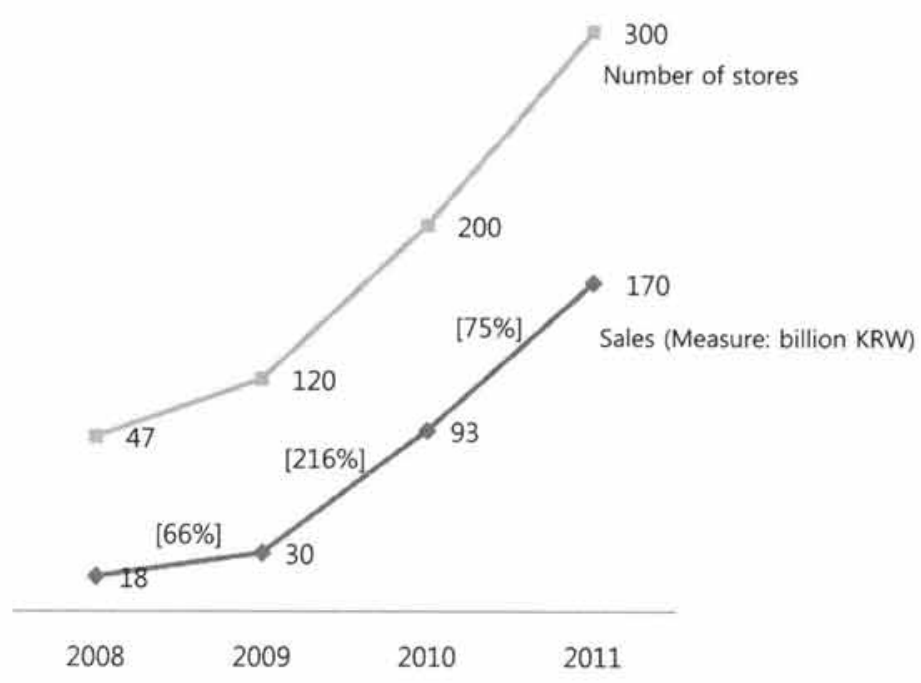

Source: the internal data of TONYMOLY 
〈Exhibit 2〉 Global Status of TONYMOLY

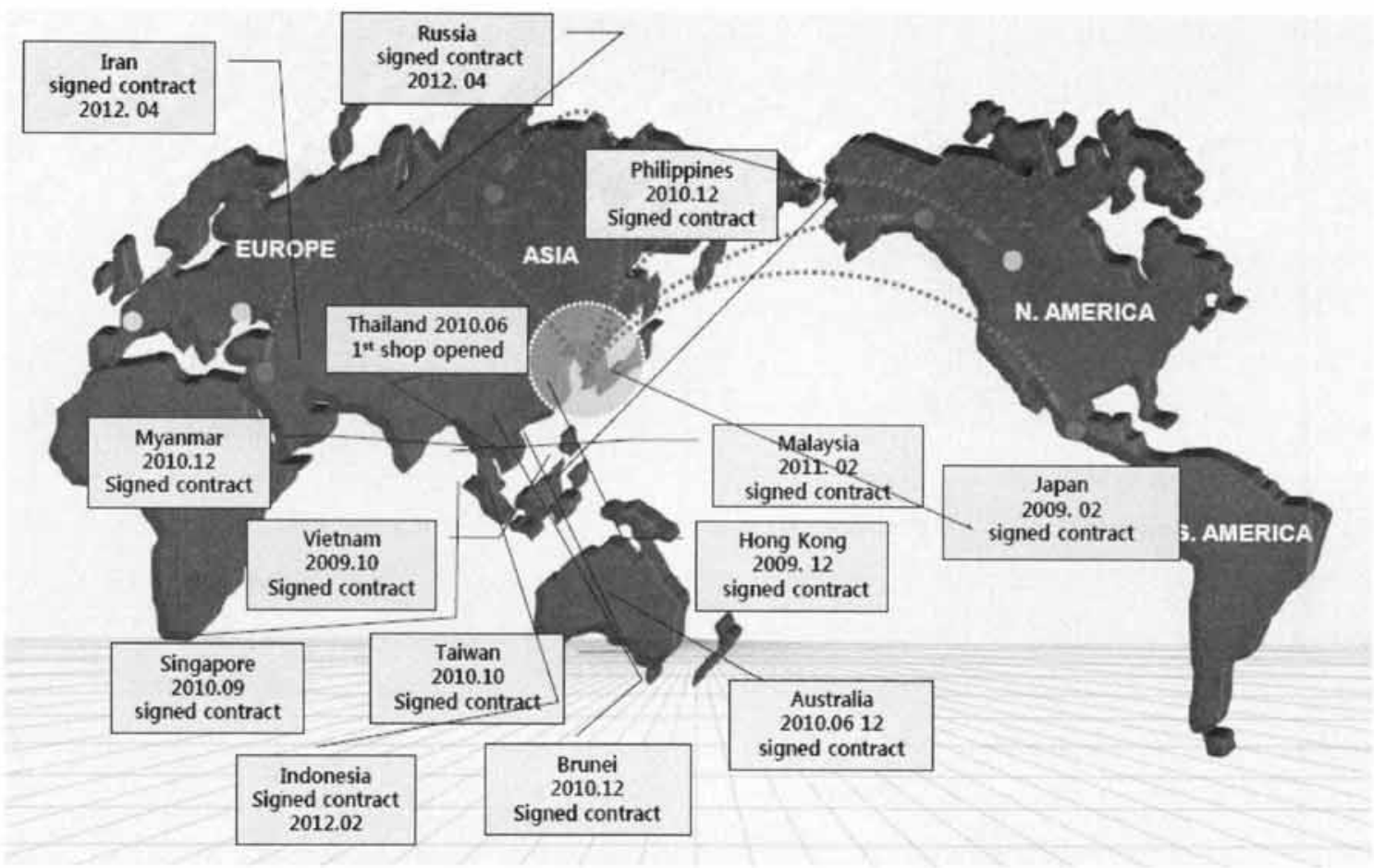

Source: the internal data of TONYMOLY

〈Exhibit 3〉 Average Transaction Value per Customer \& Average Number of Monthly Transactions of TONYMOLY

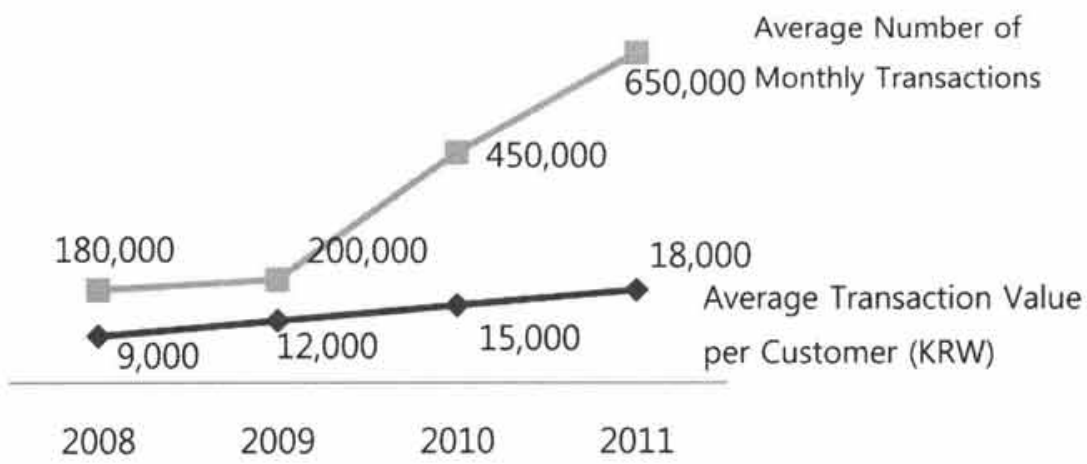

Source: the internal data of TONYMOLY 
1.2 TONYMOLY's Market-Based Performances

\subsubsection{Industry Situation}

Starting from 2003, the Korean cosmetic market has shown a steady growth. As seen in Exhibit 4 , the recovery of cosmetic market, which started in 2003, went along with the recovery of private consumption and growth in real GDP. at least up to 2007. Above anything during this period, a breakthrough change occurred in the distribution channel of cosmetic market. In the past, consumers used to think that they needed to go either department store or cosmetic specialty store to buy cosmetic products.
From 2002, the third channel type called "one brand-shop began to appear. Since then, the brand shops went into the period of heyday due to innovation in terms of price level, quality level, and distribution methods. People who were unfamiliar with the name of brand shops per se now feel very accustomed to visiting the brand shops for their purchase of cosmetic products. As seen again in Exhibit 4, the development of brand shops explains the recent growth of Korean cosmetic market. Moreover, the channels of department stores and brand shops have driven the growth of Korean $\cos ^{-}$ metic market such that the cosmetic market appears to be insensitive to economic cycles and/or fluctuations from 2007 up to now. It would

\section{〈Exhibit 4>Trends of Macro-Economic Factors \& Cosmetic Market Size}

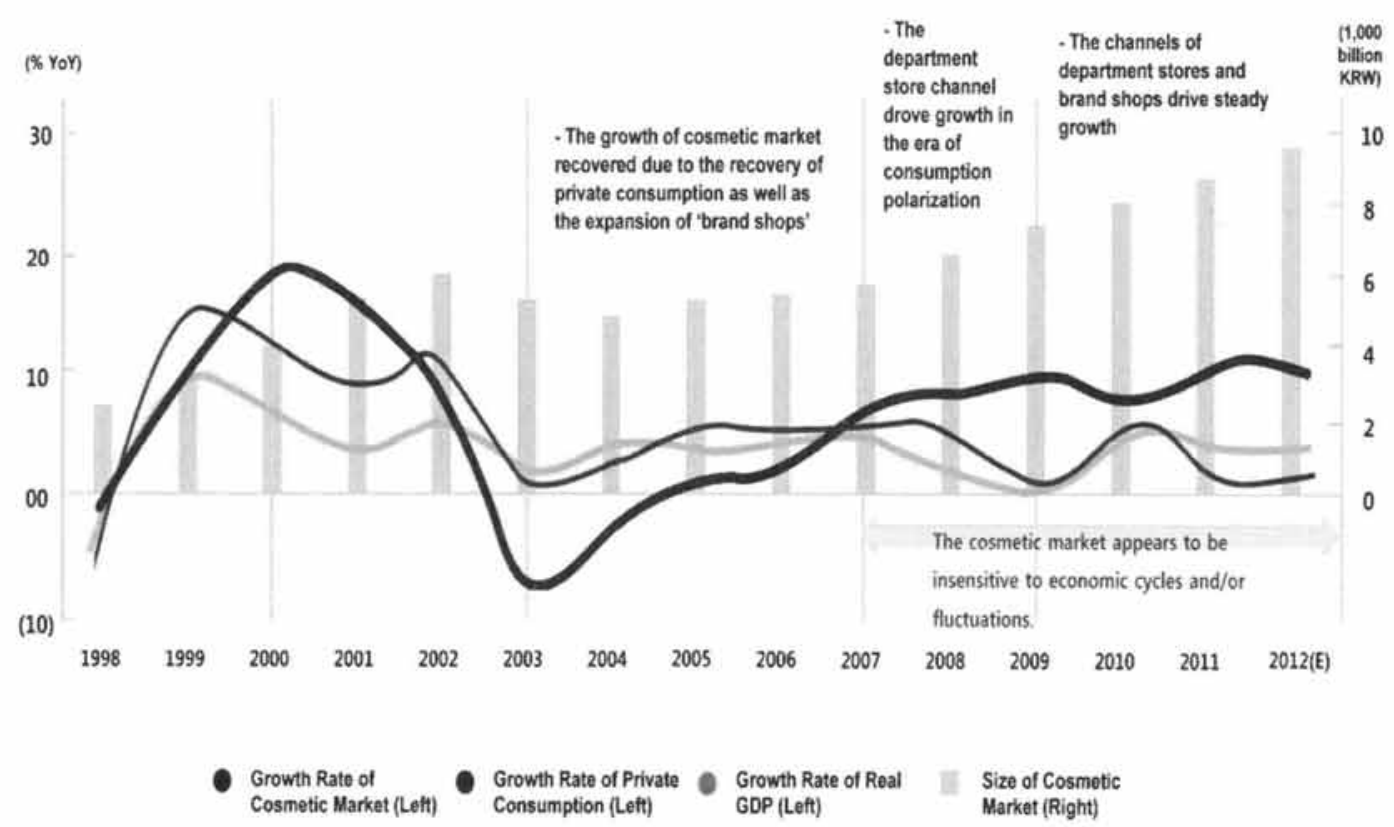

Source: Industry Report of KB Securities (December. 2012) 
be very interesting to examine what factors other than the new type of channel may explain the steady growth of Korean cosmetic market to the extent which the market grows regardless of economic factors.

\subsubsection{CEO, Mr. Joong Cheon Kim's Judgment}

When it was asked of Mr. Joong Cheon Kim what made him decide to accept the offer of working for TONYMOLY, he answered as follows. "When I make a decision as to the job to work for, I consider three aspects: 1) the status of internal operation, 2) the external market situation and 3) the issue of connection between internal operation and external market situation." For the matter of internal operation, Mr. Joong Cheon Kim not only formed the high trust toward the positive mindset of Mr. Hae Dong Bae, chairman and founder of TONYMOLY but also thought that the packaging company Mr. Chairman operates could create substantial synergy with TONYMOLY. As per the external situation, Mr. Kim thought over how the Korean cosmetic market could further be developed, judging that about $\$ 1$ billion market could be additionally developed within 10 year period as well as that the expected market size might be expanded more due to the purchase by ever-increasing inbound tourists from China and Japan than expected (see $\langle$ Exhibit 5〉). Accordingly, he viewed that TONYMOLY could take a certain share of this increasing market. Lastly, the connection of internal operation to external market situation was judged to depend upon what human resources of TONYMOLY could do, which was construed to be a challenging but possible task.

About six or seven major brands have fiercely competed in the cosmetic brand shop category in Korea. They are the Face Shop, Missha, Etude House, Innisfree, Skin Food, and TONYMOLY in the order of sales revenue and market shares of 2011 (see 〈Exhibit 6)).' Using the proportion of sales revenues by the types of distribution stores, the Face Shop and Skin Food appeared to be relatively strong in the type of store-in-mart stores, while Missha, Etude House, and TONYMOLY were strong in the types of road shop and tax-free shop stores. As briefly mentioned before, the increasing purchase of cosmetic products by Chinese and Japanese tourists may well account for the emergence of tax-free shop stores. Moreover, the Face Shop (LG Household \& Healthcare), Etude House, and Innisfree (both belong to Amore-Pacific) are owned and operated by the large companies.

1) Please note that the numbers shown in Exhibit 6,7 , and 8 may not reflect the reality perfectly because those are calculated on the basis of the data provided by TONYMOLY. If the numbers are wrong, it indicates that TONYMOLY may not sense the competitive situation perfectly. Please keep in mind that the numbers and figures of this case may well be interpreted such that readers can enhance understanding and application of marketing-related knowledge. 
〈Exhibit 5〉 Recent Data of Inbound Tourists from Asian Countries (2007 2011)

\begin{tabular}{|c|c|c|c|c|c|c|c|c|c|c|}
\hline \multirow{2}{*}{ Countries } & \multicolumn{2}{|c|}{2007} & \multicolumn{2}{|c|}{2008} & \multicolumn{2}{|c|}{2009} & \multicolumn{2}{|c|}{2010} & \multicolumn{2}{|l|}{2011} \\
\hline & $\begin{array}{c}* \text { of tourists } \\
\text { (shure) }\end{array}$ & $\begin{array}{l}\text { Growth } \\
\text { Pane (\%) }\end{array}$ & $\begin{array}{l}\text { \# of tourists } \\
\text { (share) }\end{array}$ & $\begin{array}{l}\text { Grouth } \\
\text { Rate (9) }\end{array}$ & $\begin{array}{c}\text { \# of tourists } \\
\text { (share) }\end{array}$ & $\begin{array}{l}\text { Growth } \\
\text { Rate (6) }\end{array}$ & $\begin{array}{l}\text { \# of tourists } \\
\text { (share) }\end{array}$ & $\begin{array}{l}\text { Growth } \\
\text { Rate (o) }\end{array}$ & $\begin{array}{l}\text { \# of tourists } \\
\text { (share) }\end{array}$ & $\begin{array}{l}\text { Grouth } \\
\text { Rate (b) }\end{array}$ \\
\hline Total & $\begin{array}{r}6.448 .240 \\
(100 \%)\end{array}$ & 4.8 & $\begin{array}{r}6.890 .841 \\
\left(100^{\circ} \circ\right)\end{array}$ & 6.9 & $\begin{array}{r}7.817 .533 \\
(100 \%)\end{array}$ & 13.4 & $\begin{array}{r}8.797 .658 \\
(100 \%)\end{array}$ & 12.5 & $\begin{array}{r}9.794 .796 \\
(100 \%)\end{array}$ & 11.3 \\
\hline Asia Total & $\begin{array}{r}4.683 .231 \\
(72.6 \%)\end{array}$ & 2.9 & $\begin{array}{r}5.018 .219 \\
(72.8 \%)\end{array}$ & 7.2 & $\begin{array}{r}6.005 .049 \\
(76.8 \%)\end{array}$ & 19.7 & $\begin{array}{r}6.749 .222 \\
(76.7 \%)\end{array}$ & 12.4 & $\begin{array}{r}7.662 .129 \\
(78.20 \%)\end{array}$ & 13.5 \\
\hline Japan & $\begin{array}{r}2.235 .963 \\
(34.7 \%)\end{array}$ & -4.4 & $\begin{array}{r}2.378,102 \\
(34.5 \%)\end{array}$ & 6.4 & $\begin{array}{r}3,053.311 \\
(39.1 \%)\end{array}$ & 28.4 & $\begin{array}{r}3.023,009 \\
(34.4 \%)\end{array}$ & -1 & $\begin{array}{r}3.289 .051 \\
(33.6 \%)\end{array}$ & 8.8 \\
\hline China & $\begin{array}{r}1.068 .925 \\
(16.6 \%)\end{array}$ & 19.2 & $\begin{array}{r}1.167 .891 \\
(17.0 \% 6)\end{array}$ & 9.3 & $\begin{array}{r}1.342 .317 \\
(17.2 \%)\end{array}$ & 149 & $\begin{array}{r}1.875 .157 \\
(21.3 \%)\end{array}$ & 39.7 & $\begin{array}{r}2.220 .196 \\
(22.7 \%)\end{array}$ & 18.4 \\
\hline Taiwan & $\begin{array}{r}335.224 \\
(5.2 \%)\end{array}$ & -0.9 & $\begin{array}{r}320.244 \\
(4.7 \%)\end{array}$ & -4.5 & $\begin{array}{r}380.628 \\
(4,9 \%)\end{array}$ & 18.9 & $\begin{array}{r}406.352 \\
(4.6 \%)\end{array}$ & 6.8 & $\begin{array}{r}428.208 \\
(4.4 \%)\end{array}$ & 5.4 \\
\hline Philippines & $\begin{array}{r}263,799 \\
(4.1 \%)\end{array}$ & 6.3 & $\begin{array}{r}276.710 \\
(4.0 \%)\end{array}$ & 4.9 & $\begin{array}{r}271.962 \\
(3.5 \%)\end{array}$ & -1.7 & $\begin{array}{r}297.452 \\
(3.4 \%)\end{array}$ & 9.4 & $\begin{array}{r}337.268 \\
(3.4 \%)\end{array}$ & 13.4 \\
\hline Hong Kong & $\begin{array}{r}140.138 \\
(2.2 \%)\end{array}$ & -1.9 & $\begin{array}{r}160.325 \\
(2.3 \%) \\
\end{array}$ & 14.4 & $\begin{array}{r}215.769 \\
(2.8 \%)\end{array}$ & 34.6 & $\begin{array}{r}228.582 \\
(2,6 \%)\end{array}$ & 5.9 & $\begin{array}{r}280,849 \\
(2.9 \%)\end{array}$ & 22.9 \\
\hline Thailand & $\begin{array}{r}146,792 \\
(2.3 \%)\end{array}$ & 14.2 & $\begin{array}{r}160.687 \\
(2.3 \%)\end{array}$ & 9.5 & $\begin{array}{r}190.972 \\
(2.4 \%)\end{array}$ & 18.8 & $\begin{array}{r}260,718 \\
(3.0 \%)\end{array}$ & 36.5 & $\begin{array}{r}309.143 \\
(3.2 \%)\end{array}$ & 18.6 \\
\hline
\end{tabular}

Source: http://www.tour.go.kr/main.asp

〈Exhibit 6> Sales Revenue and Market Share of Brand Shop Brands by Store Types (2011)

\begin{tabular}{|c|c|c|c|c|}
\hline Brands & $\begin{array}{c}\text { Sales Revenue } \\
\text { (Share) }\end{array}$ & $\begin{array}{c}\text { Sales of Road Shops } \\
\text { (Share) }\end{array}$ & $\begin{array}{c}\text { Sales of Duty-Free } \\
\text { Stores (Share) }\end{array}$ & $\begin{array}{c}\text { Sales of Stores-in- } \\
\text { Marts (Share) }\end{array}$ \\
\hline The Face Shop & $3,760(24.9 \%)$ & $2,000(19.9 \%)$ & $190(14.5 \%)$ & $1,570(42.2 \%)$ \\
\hline Missha & $2,800(18.6 \%)$ & $1,950(19.4 \%)$ & $380(29.1 \%)$ & $470(12.6 \%)$ \\
\hline Etude House & $2,630(17.4 \%)$ & $1,870(18.6 \%)$ & $410(31.3 \%)$ & $350(9.4 \%)$ \\
\hline Innisfree & $2,280(15.1 \%)$ & $1,880(18.7 \%)$ & $60(4.6 \%)$ & $340(9.1 \%)$ \\
\hline Skin Food & $1,960(13.0 \%)$ & $1,200(11.9 \%)$ & $50(3.8 \%)$ & $710(19.1 \%)$ \\
\hline Tonymoly & $1,650(10.9 \%)$ & $1,150(11.4 \%)$ & $220(16.8 \%)$ & $280(7.5 \%)$ \\
\hline Total & $15,080(100 \%)$ & $\begin{array}{c}10,050(100 \%) \\
66.6 \% \text { of Total Sales }\end{array}$ & $\begin{array}{c}1,310(10 \%) \text { of Total Sales } \\
24.7 \%\end{array}$ & $\begin{array}{c}3,720(100 \%) \\
\text { of Total Sales }\end{array}$ \\
\hline
\end{tabular}

Source: calculated based on the data provided by TONYMOLY

(Unit: 100 million Korean Won) 
Skin Food is owned and managed by the old comprehensive cosmetic company called iPEERES. On the other hand. Missha and TONYMOLY are relatively small but fast-moving companies specializing in brand-shop cosmetics. Especially, Missha has been regarded the pioneer which created the low-price cosmetic category of brand-shop in the first place. Nowadays, as seen in Exhibit 6, competition is very fierce in the brand-shop category but it appears to play the positive role in expanding the total sales revenues of brand shop cosmetic brands (Aghion and Griffith 2008). Assessing the proportion of sales revenues by road shops and tax-free shops, TONYMOLY seems a smart and fast follower which importantly considers sales effectiveness and efficiency.

The sales of brand shop competitors can be evaluated in terms of sales efficiency. How efficiently sales are made can be assessed by the measure such as share of sales revenue divided by share of store numbers. As seen in Exhibit 7. given that the Face Shop and Skin Food indicated the relatively low level of sales efficiency, these brands may have taken a relatively low-price seller position, emphasizing

〈Exhibit 7〉 Sales Efficiency of Brand-Shop Cosmetic Brands (2011)

\begin{tabular}{|c|c|c|c|c|}
\hline \multirow{2}{*}{ Brands } & $\begin{array}{c}\text { \# of total stores } \\
\text { (share) }\end{array}$ & $\begin{array}{c}\text { \# of road shops } \\
\text { (share) }\end{array}$ & $\begin{array}{l}\text { \# of tax-free } \\
\text { shops (share) }\end{array}$ & $\begin{array}{c}\# \text { of mart stores } \\
\text { (share) }\end{array}$ \\
\hline & $\begin{array}{c}\text { Sales Efficiency }= \\
\text { (share of sales } \div \text { share } \\
\text { of stores) }\end{array}$ & Sales Efficiency & Sales Efficiency & Sales Efficiency \\
\hline \multirow{2}{*}{ The Face Shop } & $968(31.8 \%)$ & $588(29.9 \%)$ & $20(25.3 \%)$ & $360(36.2 \%)$ \\
\hline & 0.78 & 0.67 & 0.57 & 1.17 \\
\hline \multirow{2}{*}{ Missha } & $487(16.0 \%)$ & $358(18.2 \%)$ & $14(17.7 \%)$ & $115(11.6 \%)$ \\
\hline & 1.16 & 1.07 & 1.64 & 1.09 \\
\hline \multirow{2}{*}{ Etude House } & $357(11.7 \%)$ & $240(12.2 \%)$ & $16(20.3 \%)$ & $101(10.2 \%)$ \\
\hline & 1.49 & 1.53 & 1.55 & 0.93 \\
\hline \multirow{2}{*}{ Innisfree } & $453(14.9 \%)$ & $332(16.9 \%)$ & $9(11.4 \%)$ & $112(11.3 \%)$ \\
\hline & 1.02 & 1.11 & 0.40 & 0.81 \\
\hline \multirow{2}{*}{ Skin Food } & $457(15.0 \%)$ & $240(12.2 \%)$ & $3(3.8 \%)$ & $214(21.5 \%)$ \\
\hline & 0.87 & 0.98 & 1.01 & 0.89 \\
\hline \multirow{2}{*}{ Tonymoly } & $321(10.6 \%)$ & $212(10.8 \%)$ & $17(21.5 \%)$ & $92(9.3 \%)$ \\
\hline & 1.04 & 1.06 & 0.78 & 0.81 \\
\hline Total \# of Stores & $3.043(100 \%)$ & $\begin{array}{c}1.970(100 \%) \\
64.7 \% \text { of Total } \\
\text { Stores }\end{array}$ & $\begin{array}{c}79(100 \%) \\
2.6 \% \text { of Total } \\
\text { Stores }\end{array}$ & $\begin{array}{c}994(100 \%) \\
32.7 \% \text { of Total } \\
\text { Stores }\end{array}$ \\
\hline
\end{tabular}

Source: calculated based on the data provided by TONYMOLY 
〈Exhibit 8〉 The Monthly Average Sales per Store of Competing Brands (2010 2012)

\begin{tabular}{|c|c|c|c|}
\hline Brands & Average of 2010 & Average of 2011 & Average of 2012 \\
\hline Etude House & 6,080 & 6,890 & 7,340 \\
\hline Innisfree & 4,160 & 4,960 & 5,600 \\
\hline Tonymoly & 4,110 & 4,740 & 5,480 \\
\hline Missha & 4,860 & 4,400 & 4,760 \\
\hline Skin Food & 3,820 & 3,610 & 3,900 \\
\hline The Face Shop & 3,570 & 3,360 & 3,560 \\
\hline
\end{tabular}

(Unit: 10,000 Korean Won)

Source: calculated based on the data provided by TONYMOLY

volume-based selling. The Face Shop displayed a strong efficiency in mart store type. On the other hand, Etude House showed the relatively high efficiency, probably taking a relatively high-price seller position. Missha, Innisfree, and TONYMOLY displayed the medium level of sales efficiency. Specifically, TONYMOLY has a more room of improvement in the sales efficiencies of tax-free shops and mart stores. Furthermore, based on the trend of monthly average sales per store for competing brands (see $\langle$ Exhibit 8〉), Etude House, Innisfree, and TONYMOLY appear to have grown in recent years, although much care has to be taken in the respect that the data only show the average data, not the variances.

\section{Differentiation Efforts and Targeting of TONYMOLY}

\subsection{TONYMOLY's Differentiation Efforts}

Mr. Joong Cheon Kim (the marketing leader as well as (EO) and his marketing team members have been continuously discussing how to differentiate TONYMOLY products from competing branded products. Indeed, the differentiation efforts have evolved from the fundamental marketing principle of providing value to consumers, which is assessed to be the emergent approach to strategy-making (Mintzberg 1994). As a relatively late entrant into the cosmetic brand-shop category, TONYMOLY creates and manages four value propositions through its marketing programs: i) developing and marketing value brand, ii) utilizing unique in- 
gredients, iii) unique packaging, and iv) continuous innovation \& steady hit-selling products.

First, with continuous communication with customers and R\&D investment, TONYMOLY's core value proposition was decided to provide the competitively high value with customers by developing to market high quality products with reasonable price level. In this sense, the core benefit of TONYMOLY products is value (Kotler and Armstrong 2009). The following is the excerpt from the interview with CEO (Mr. Joong Cheon Kim), which accounts for the concept of value.

"Our weapons for differentiation are composed of broad product line which can respond to various consumer needs, product development efforts of launching high quality products through continuous $R \& D$ investment, and technological alliances with foreign expert companies.

TONYMOLY intends to be positioned as 'good enough' brand with high quality products but 'good-hearted" price in consumers' minds."

Second, on the platform of 'value' brand concept, TONYMOLY decided to augment the actual product by utilizing unique ingredients such as snail mucus essence, bee veno, swellfish collagen, and Syn-Ake (pseudo peptide that mimics real snake venom). For instance, TONYMOLY 'Intense Repair Live Snail' line, which contains high concentrations of wild South Korean snail mucus essence, is famous for Korean and Asian women for activating skin cells as well as improving collagen to repair the damaged skin.
The imitative efforts by competing products (imported as well as local) using a similar ingredient (i.e., snail mucus essence) appeared to make TONYMOLY 'Intense Repair Live Snail' line more attractive in the functional skin care product segment, which can be regarded as the positive effect of competition (Aghion and Griffith 2008). In fact, this kind of marketing efforts has been suggested to be effective in the literature of signaling effects (i.e., use an intrinsic product characteristic such as an ingredient to signal the high level of product quality to consumers: Rao and Monroe 1988: Scitovsky 1945).

Third, TONYMOLY has strengthened brand awareness and attention by creating 'fun' value through unique packaging (See $\langle$ Exhibit 9〉). For example, TONYMOLY's 'Red Appletox Honey' cream contains natural honey extracts, while the apple-shaped packaging emphasizes the natural and organic ingredients without sacrificing quality and functionality. In addition, TONYMOLY's million seller, the 'Backstage Gel' eye-liner also provides top-quality beauty through stylish and effective all-in-one packaging (i.e., eyeliner and brush are in one packaging). This single product accounted for $5 \%$ of total sales. Not only getting consumer attention through fun, TONYMOLY's unique packages have been playing the role of POP (point of purchase) materials. The advantage of TONYMOLY in terms of unique packaging is largely due to the packaging capability of its 
parent company, Taesung Industry, which is one of its core competencies. As in the case of ingredients, TONYMOLY's unique packaging has also brought about the imitative efforts of competing brands.

The last dimension of TONYMOLY's differentiation efforts lies in its continuous introduction of new products. TONYMOLY has a portfolio of various products that give solutions of different functions and skin conditions for the different age groups. With each new and exciting product, TONYMOLY's various skin care lines provide beauty experience of top quality with the target consumers. For less than two years, TONYMOLY has introduced many hitselling product lines such as Floria series, Honey Bee series, Timeless EGF, and Intense Care-Sye Ake series. In addition, TONYMOLY has many steady-selling products. For instance, Backstage
Gel eye-liner, as just one product item, has recorded the sales revenue mark of approaching toward 10 billion won per year for the last three years. Moreover, Chrystal blusher, Luminous Aura BB cream and Nutra-Energy toner have been ranked as number 1 in the blind tests of 'Get It Beauty' program (one of famous beauty cable channel programs in Korea). The sales of two hit products, namely Backstage Gel eye-liner and Snail cream, rise from 12.7 billion won in the first half of 2011 to 15.4 billion won in the first half of 2012. TONYMOLY's continuous successes in product development efforts may well contribute to forming the perceived personality of TONYMOLY brand as the 'competent and expert' brand (Aaker 1997).

In sum, TONYMOLY's various efforts of differentiating its products appear to appeal to utilitarian needs such as value, unique in-

〈Exhibit 9> The Examples of Unique Packaging by TONYMOLY

Red Appletox Honey Cream

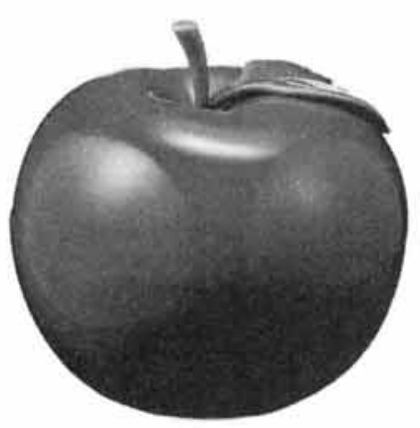

Backstage Gel Eyeliner

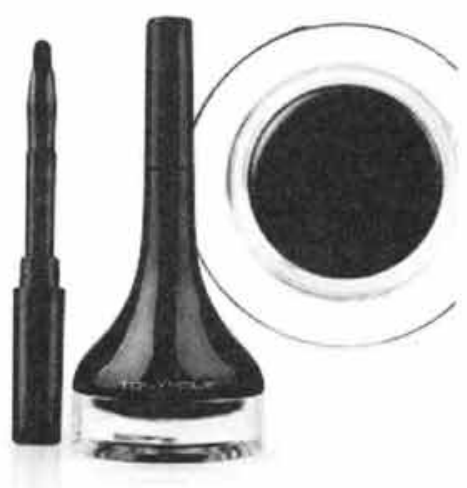

Source: www.etonymoly.com 
gredients, and new products as well as hedonic needs such as fun-packaging (Chaudhuri and Holbrook 2001).

\subsection{TONYMOLY's Targeting}

According to $\mathrm{CEO}$ now and marketing leader in the past (Mr. Joong Cheon Kim), the primary target customer group was female of middle-to-late teens, the age group who just started a makeup when TONYMOLY started its business mainly because it wanted to uniquely appeal to the consumer segment which competitors used to consider as a secondary, not a primary, target group. Furthermore, this group was judged to just start a makeup and be more open to a new player and its products as long as the basic quality of products was guaranteed. In other words, TONYMOLY was well aware of the enormous resource power of competitors, avoiding the direct confrontation with them, also gaining time for nourishing competences in the future competition to come. Based on successfully penetrating into this foothold customer group, TONYMOLY began to expand its target customer groups toward twenties and thirties by developing and launching the products for these different age groups. In the present, some products are commonly popular in all the age groups, while there are a few products accepted well by the respective age groups (see $\langle$ Exhibit 10〉).

\section{Marketing Communications}

"Our company is relatively a small player. We cannot afford a large amount of marketing communication budget. We should be unique and smart enough to efficiently use our marketing communication money (CEO, TONYMOLY)."

Accordingly, the number one principle of TONYMOLY in terms of marketing communications was to consider the media-usage behaviors of its target customers in detail so that it could make smart decisions as to when, where, and how much to use its marketing communication budget.

\subsection{TONYMOLY's Unique Approach to Media Planning and Execution}

Traditional form of advertising media such as television and print ads are not the main communication channels for TONYMOLY. Whereas major competitors such as Missha, Skin Food and the Face Shop heavily use traditional media to attract a large number of potential consumers, TONYMOLY has been selecting and focusing on a few communication channels including new media which are frequently accessed by their target customers. The primary target customers of TONYMOLY are females in late $10^{\circ}$ s and $20^{\circ} \mathrm{s}$. They are spending more time on Internet than TV and fashion magazines. 
〈Exhibit 10〉 The Products by Sales Order for the Different Age Groups

\begin{tabular}{|c|c|c|c|c|}
\hline $\begin{array}{l}\text { The Order } \\
\text { of Sales }\end{array}$ & $\begin{array}{l}\text { The Products for } \\
\text { All Age Groups }\end{array}$ & $\begin{array}{c}\text { The Products for } \\
\text { Teens }\end{array}$ & $\begin{array}{c}\text { The Products for } \\
\text { Twenties }\end{array}$ & $\begin{array}{c}\text { The Products for } \\
\text { Thirties }\end{array}$ \\
\hline 1 & 풀로리아학이트넘켭슐여눈스 & 플로리아악이트넉컹술에선스 & 풀로리아학이트넘갰슐 여샌스 & 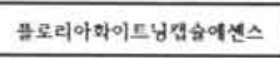 \\
\hline 2 & tV선셧바디 \& 펴일리선크림 & tV선샛바디 \& 폐밀리선크람 & 플로리아학이트넝토너 & 퓰로리아항이트넘토너 \\
\hline 3 & 퓰로리아학이트넝토너 & tV선셧멱시몀선붚록크림: & 너선젓바디 \& 폐일리선크림 & t7선샛멱시엄천귝독크림: \\
\hline 4 & TT선샛멱시명선븜옥크림: & 백스테이지졀아이라이너-2.호 브라 & t7선샛맥시멈선귝옥크림: & 나선셧바디 \& 피밀리선크림 \\
\hline 5 & 인톤스겨어스니일크림3 & 백스텨이지풀아이라이너-1호. & 백스텨이지종아이락이너-1호플력 & 인토스거어스녀일크랭3 \\
\hline 6 & $\begin{array}{c}\text { 벽스터이지졀아이라이녀- } \\
\text { 1호ㅆㅠㅠ력 } \\
\end{array}$ & 플로리아학이트넝토너 & 퓰로리아뉴트라-여너지토너 & 인몬스커어스녀있예선스 3 \\
\hline 7 & 푤로리아뉴트라-여너지도너 & 루미너스여신팡치BB 크렴 & 인텬스거어스너일크림3 & 플로리아뉴트라-여너지토너 \\
\hline 8 & 벽스텨이지깰아이락이너-:호. & tT선솟대일리선크림SPF30 & 땍스텨이지잴아이라이너-2호브라 & 타임리스플라선타크링 \\
\hline 9 & 후미너스여신팡재BB 크림 & 다선솟키즈\& 맘선크림 & 루미너스어신팡쥬미스트 & 프려스티지키럿스마태빕비크림 \\
\hline 10 & tV선샛팍우더리피니위선밀크 & [4앨호력]뗙젤락이너_뷸력 & 프러스티지게릿스마탭비버크림 & 다임리스이지여프파웍에샌스 \\
\hline 11 & 프려스티지크릿스마텸비비림 & tT천샛파우더리피니쉬선 밀크 & 를리어매직림 \& 아이리무버NEW : & tT선샛키즈\& 맘선크림 \\
\hline 12 & 인턴스거어스녀일예선스 3 & 토니틷트:-1호제리명크 & 리열터치 진동며프 & tT선샛파우더리피니쉬선키크 \\
\hline 13 & 루미너스여신망졔미스도 & 투미너스여신팡재미스트. & 플로리아뉴트라-여너지여멸전 & 리얼터치 진동퍼프 \\
\hline 14 & 타임리스푤라선타크링 & 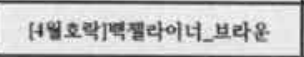 & 릴약성아쿠아마릴서벗 콜혈저: & 무미너스여신명재미스트 \\
\hline 15 & 너선샛키즈 \& 맘선크림 & 웍터잴리틸프2호육기잴리 & 땍시파웍줏찔리ㄹㅣㅣ퀴드 & 멱시파웍풋째링리카트 \\
\hline 16 & 27선샛 4 일리선크림SPF30 & 크리스탈휼러셔7호-브혼정브라 & t7선셧파우더리피니쉬선밀크 & 인텬스케어스녀일선크림 \\
\hline 17 & 리열터치 진옹퍼프 & 토니턷트:-2로러트예률 & 루미너스여신팡제 BB 크랑 & 플로리아학이트넘크림 \\
\hline 18 & 플로리아뉴트라-여너지여멸전 & 토마톡스매적확이트마사지력 & 인텬슼1어스네일예춴스 3 & 후미너스여신평졔BB 크림 \\
\hline 19 & 렬리어매직립 $\&$ 아이리무버 & 굴리어 매직릴 \& 아이리무버 & 크리스탈퀄러서7호-브롤징브라 & 타임리스이지에프파웍크렴 \\
\hline 20 & 맥시파워뭊필링리퀴드 & 플로리아뉴트라-여너지토너 & 흘로리아왁이트넘크림 & 타업리스이지여 프팍웍아이크링 \\
\hline
\end{tabular}

Source: the internal data of TONYMOLY

They are more sensitive to online reviews of other people including their friends and power bloggers.

\subsubsection{Viral Marketing}

The key communication strategy of TONYMOLY has been so-called 'viral marketing.' Specifically, TONYMOLY has utilized expertise such as make-up artists and power bloggers who have many followers (fans). Traditionally, famous Korean make-up artists used expensive imported cosmetic brands since they did not have confidence in the quality and functionality of Korean cosmetic brands. In order to be accessible to famous make-up artists, TONYMOLY first asked them to compare TONYMOLY's major products with famous imported brand products. The test results turned out to be unexpectedly favorable. For example, 'Party Lover' 
gel eye-liner was proven to be much better in quality and functionality compared to most famous imported brand products of gel eye-liner. Make-up artists who had reviewed TONYMOLY's products posted their opinions and reviews on their own blogs with demonstrations on stepby-step make-up skills anyone could easily follow. Since then, consumer responses were explosive such that the sales of 'Party Lover' gel eyeliner grew at $1,000 \%$. The concept of this activity is, to a certain extent, akin to the classic campaign of Pepsi Challenge (blind taste comparison tests of Coke versus Pepsi: Barney 1995).

TONYMOLY used the similar strategy for power bloggers who were active in major cosmetic communities. Power bloggers were asked to evaluate TONYMOLY's products. As power bloggers started posting their candid evaluations. the event happened such that TONYMOLY ranked the number 1 keyword in major portals. As many followers added more opinions and reviews, TONYMOLY quickly became the wellknown brand among potential target customers.

\subsubsection{PPL (Product Placement)}

Another successful element of TONYMOLY's communication strategy lied in utilizing PPL (Product Placement) in the 'Variety' programs of major broadcasting TVs. For instance, in 2009. TONYMOLY chose top-rated variety programs such as 'We Just Married' program of $\mathrm{MBC}$. In particular, under the limited resources, TONYMOLY chose a concentrated strategy where a few main products were intensively exposed within a short period of time. For example. TONYMOLY's unique and fun products such as 'Tomatox' brightening mask and 'Appletox' smooth massage peeling cream were visible in main variety shows, which increased awareness and sales and subsequently stimulated positive word-of-mouth online and offline.

\subsubsection{The Use of Celebrities \& TV Advertising}

Although TONYMOLY has relied more on viral marketing than mass media approach, TV commercials have been complementarily used to increase the reach. Instead of running TV commercials continuously, TONYMOLY has advertised on TV in a very concentrated manner during a very short time span to efficiently use their advertising budget. Each year. TONYMOLY ran one TV commercial, and each commercial ran for two or three months. The main feature of TV commercials could be identified in its use of celebrity, so called idol models that were famous to main target customers such as Kim, Hyun Joong (2008) and Song, Joong Ki \& T-Ara (2011). TONYMOLY's models of 2012 were Min, Hyo Rin and JYJ. 


\subsection{Assessment of TONYMOLY's Marketing Communications}

With its efficient and effective communication strategy, TONYMOLY has been able to achieve the highest communication performances. TONYMOLY's advertising expenditure used to be the lowest among competitors (2.5 billion won: share of advertising $=3.6 \%$ ). That is, compared to total sales. TONYMOLY spent advertising expenses less than any other competitors in 2011 (see 〈Exhibit 11〉). For instance, in 2011. Missha, the second player in the market spent about $8.4 \%$ of their total sales on advertising, whereas TONYMOLY's advertising expenses explained $1.5 \%$ of its total sales. Other two major players, the Face Shop and Etude House, spent about 3\% of their total sales on advertising. It can, then, be judged that TONYMOLY's unique approach to media planning and execution such as viral marketing and PPL produced communication performances efficiently and effectively, making TONYMOLY deserve to be called a "smart marketing player.'

\section{Relationship Marketing}

\subsection{Customer Relationship Marketing}

TONYMOLY has successfully managed relationships with their customers through its

〈Exhibit 11〉 The Total Sales, Advertising Expenditure, and

Advertising to Sales Ratio of Brand-Shop Brands in 2011

\begin{tabular}{|c|c|c|c|c|}
\hline Brands & $\begin{array}{c}\text { Total Sales } \\
\text { (Market Share) }\end{array}$ & $\begin{array}{c}\text { Advertising } \\
\text { Expenditure } \\
\text { (Share of Voice) }\end{array}$ & $\begin{array}{l}\text { Ad Effectiveness } \\
=\text { Market Share/ } \\
\text { Share of Voice }\end{array}$ & $\begin{array}{l}\text { Ad to Sales } \\
\text { Ratio }\end{array}$ \\
\hline The Face Shop & $\begin{array}{c}3.760 \\
(24,9 \%) \\
\end{array}$ & $\begin{array}{c}109 \\
(15.8 \%) \\
\end{array}$ & 1.58 & $2.9 \%$ \\
\hline Missha & $\begin{array}{c}2.800 \\
(18.6 \%) \\
\end{array}$ & $\begin{array}{c}236 \\
(34.3 \%) \\
\end{array}$ & 0.54 & $8.4 \%$ \\
\hline Etude House & $\begin{array}{c}2.630 \\
(17.4 \%) \\
\end{array}$ & $\begin{array}{c}73 \\
(10.6 \%) \\
\end{array}$ & 1.64 & $2.8 \%$ \\
\hline Innisfree & $\begin{array}{c}2.280 \\
(15.1 \%) \\
\end{array}$ & $\begin{array}{c}110 \\
(15.9 \%) \\
\end{array}$ & 0.95 & $4.8 \%$ \\
\hline Skin Food & $\begin{array}{c}1,960 \\
(13.0 \%) \\
\end{array}$ & $\begin{array}{c}135 \\
(19.7 \%) \\
\end{array}$ & 0.66 & $6.9 \%$ \\
\hline TONYMOLY & $\begin{array}{c}1,650 \\
(10.9 \%)\end{array}$ & $\begin{array}{c}25 \\
(3.6 \%) \\
\end{array}$ & 3.02 & $1.5 \%$ \\
\hline Total & $\begin{array}{l}15,080 \\
(100 \%)\end{array}$ & $\begin{array}{c}688 \\
(100 \%) \\
\end{array}$ & - & $\begin{array}{l}4.56 \% \\
\text { (ave.) }\end{array}$ \\
\hline
\end{tabular}

Source: calculated based on the data provided by TONYMOLY

(Unit: 100 million Korean Won) 
membership program. Since TONYMOLY started the membership program in 2008, the number of members rose substantially, reaching $1,850,000$ members in October, 2012. The net increase of members from January 2012 to October 2012 is approximately 840,000 . There are three types of members: general members, VIP members, and VVIP members. TONYMOLY provides exclusive benefits with VVIP members such as $10 \%$ discount and 10\% points reward which can be used for the next purchase. In addition, TONYMOLY presents birth day coupons and sends mobile short-text messages to their members for exclusive offers, new product information, and promotions. With TONYMOLY's continuous efforts on building relationships with their customers, more than $50 \%$ of overall sales are usually generated by members, and $65 \%$ of target consumers (late $10 \mathrm{~s}$ and $20 \mathrm{~s}$ ) have repurchased TONYMOLY's products.

\subsection{Building and Managing Relationships with Franchisees}

"The success of our franchisees is our success. Responding to franchisees is same as listening to our customers since franchisees are facing customers in the frontline" said the marketing manager of TONYMOLY. TONYMOLY has maintained close relationships with franchisees in terms of implementing long-term strategies for shared growth. In order to grow together, TONYMOLY provides successful business sol- ution and strengthens the benefits to franchisees. Most of all, TONYMOLY's successful relationship with franchisees is based on the trust built and nurtured via frequent communication and interactions between TONYMOLY and its franchisees. Specifically, in every year, TONYMOLY held two seminars: domestic seminar and overseas seminar. For instance, last year, TONYMOLY brought franchisees to Kyungju and Hong Kong (E-daily News, 2011. 11.15). For every seminar, CEO and all executives participated and had interactions with franchisees. Moreover. CEO, executives and employees of TONYMOLY's main office regularly visit stores and listen to opinions and suggestions of franchisees. TONYMOLY is proud of the fact that all employees from CEO to low-level staffs are able to work as sales representatives in any TONYMOLY store since frequent visits and interactions with franchisees enable them to understand the real-world business issues in detail from the perspective of franchisees. The following article reflects the importance of on-site communication emphasized by CEO, Mr. Kim.

"His day starts with visiting TONYMOLY stores. He currently has an organic relationship with the owners of over 280 stores nationwide. I stopped by TONYMOLY stores nearby home in the morning on the way to work, CEO (Mr. Kim) said. He visits about 10 stores, feels the atmosphere in the field, and hears consumer complaints and opinions and the store owners' suggestions, on the basis of which he and his staffs identified and implemented the improved 
solutions. CEO Kim emphasizes communications with the on-site representatives due to his experiences of salesman for about 20 years ......... Since then, he made the habits of listening to voices of store owners and consumers. …..... It probably seems natural that he is making a TONYMOLY mythology proudly in peer with large corporations, who has a field-based mindset of sales orientation and bright eyes reading the trend of the market. I don't think that there is so-called a market trend. If you followed what was situated as a new trend, it would have been too late. Proactively reading and creating a trend is the virtue required of $C E O$ on the basis of diligent communication with on-site people,' CEO Kim said (The Hankook Daily Newspaper, 2011. 11. 11)."

\section{Marketing Leadership}

The leadership of $\mathrm{CEO}$ in emphasizing active communication is consistently applied in internal marketing. Mr. Kim has stressed that unconstrained conversations and communications among internal employees must have made working for the company worthwhile given the intense level of internal competition. The contents of interview with $\mathrm{CEO}$ and marketing people are summarized as follows.

The doors of TONYMOLY's executive rooms are always open. Through frank communication with executives, team leaders or junior staffs derive shiny and creative ideas and share diffi- culties with work life and personal life, seeking advices. Chief executives have been leading internal employees with the soft and strong charisma rather than the intense charisma.

Marketing leadership by $\mathrm{CEO}$ and executives is also manifested in TONYMOLY's pursuit of globalization. As mentioned in the introduction, TONYMOLY has grown by strengthening overseas business (see 〈Exhibit 2〉 again). Currently. TONYMOLY operates about 200 shops in 14 countries, especially focusing on Asian countries. As the Korean market for brand-shops approaches the ceiling of market potential, TONYMOLY cannot afford to give less weight on further penetrating into foreign markets. CEO, Mr. Kim thought in his mind that if 2012 was a foothold year for TONYMOLY to start the engine of becoming a global brand, 2013 would be the first year for TONYMOLY to grow further as a genuine global brand. Expanding the number of stores up to 1,000 in Asian market would be an ambitious but attainable goal within a few years. Further, TONYMOLY intends to make in detail the plan of developing South American market, North American market, and European market, starting from the second half of 2013. At the same time, TONYMOLY aims to continuously develop and launch hitselling products, making consumers experience and identify with our products. As Mr. Kim thinks over a lot of strategic issues, the announcement is being made that KTX approaches to the Seoul station. 


\section{Concluding Remarks}

We have, heretofore, examined the stories of TONYMOLY's recent marketing activities which may explain the plausible reasons behind the substantial growth of a small but smart cosmetic company. In this section, we not only summarize TONYMOLY's key success factors but also present major issues of future challenges.

\subsection{TONYMOLY’s Key Success Factors}

Above all, the first key success factor of TONYMOLY would be found in its adherence to the clear philosophy, in its planning and implementing marketing activities, of the customer value proposition and/or the differentiated position of TONYMOLY as a brand of providing value. Second, this brand concept of value was first penetrated and welcomed among the foothold customer target group of mid and late teens with appropriate products, while the target groups were later expanded into the age group of twenties along with expansion of relevant products. Third, its differentiation efforts have been concrete and meaningful by utilizing i) unique ingredients in its product development and marketing efforts, ii) unique fun packaging, and iii) continuously introducing new hit-selling products as well as managing steadyselling products. Fourth, TONYMOLY has been smart enough to use its limited marketing money efficiently and effectively in its marketing communication activities. Viral marketing, PPL, and concentrated media planning and execution turned out to produce effective and efficient market-based performances such as awareness, word-of-mouth, and sales. Lastly, the marketing leadership of $\mathrm{CEO}$ and top management, emphasizing communications and interactions, was confirmed in the relationship quality with and trust level of its franchisees and internal employees. These key success factors may explain the recent phenomenal market performances of TONYMOLY.

\subsection{Future Challenges}

Despite TONYMOLY's recent successes, the major issues are presented for TONYMOLY to consider for maintaining its sustainable advantages and growth. The first issue concerns TONYMOLY's choice of growth philosophy. Indeed, TONYMOLY encounters the choice of alternative philosophies in maintaining its growth: product/brand-centric marketing vis-à-vis customer-centric marketing. Specifically, TONYMOLY could always target to acquire and maintain young generation (teens and 20s) and position it as "cool \& fresh" brand among them. Or TONYMOLY focuses on current target customers and meets their needs following their life cycles. That is, as current target consumers get older, it could develop and deliver the different products for them. The question is 
whether the aging consumers continue to be with TONYMOLY products once their life stages change, the very similar issue of which was once faced by the case of Levis in its failed effort of 'Tailored Classic by Levis (Aaker 1991)." Although firms are naturally inclined to attempt to 'kill two birds with one stone,' it is very often not seemingly easy for firms to implement both philosophies of growth because their cognitive and organizational focus may get distracted. Depending upon which philosophy of growth can be taken as a major one, firms' activities of product development management and CRM may well be differently planned and executed. Which philosophy had better be the major one to TONYMOLY? What is implied by the fact that $65 \%$ of TONYMOLY's current target (teens and 20s) appears to repurchase its products? What kind of factors should TONYMOLY consider in its approach to making sustainable growth?

The second challenging issue relates to how TONYMOLY can cope with 'growing pains' plausibly accompanied with the rapid growth. TONOMOLY's high growth of top-line sales has been made possible by a rising number of stores/customers as well as a rapid globalization effort. However, as the market is going to the maturity stage, performance efficiency will soon decrease. For instance, the sales efficiency of TONYMOLY at duty-free shops appears to start to decrease. It is certain that TONYMOLY naturally considers various options of making sustainable growth. So far, TONYMOLY's strong advantage lied in its fast speed of decision making, the recent example of which was found in its smartly managing the crisis and accident originated from the problem of its main celebrity model of 'T-Ara.' As TONLYMOLY grows further, however, it is certain that TONYMOLY would transform person-based decision-making activities to system-based decision making. What kind of additional systems may be needed by TONYMOLY in its activities of management and marketing? As many systems will be introduoed, how may TONYMOLY deal with possible concerns relating to bureaucratization of organization? Moreover, how may TONYMOLY deal with management of globalization as it further seeks to grow by globalization?

Remembering the major issues of future challenges to TONYMOLY, which were recently discussed with a few marketing professors, these afore-mentioned questions also linger in the mind of CEO (Mr. Joong Cheon Kim) when he takes a taxi on the way home in front of Seoul station. 